\title{
Bone Growth with Low Bone Mineral Content in Very Low Birth Weight Premature Infants ${ }^{1}$
}

\author{
FRANK R. GREER AND ANN MCCORMICK \\ Department of Pediatrics, University of Wisconsin, Center for Health Sciences, Madison, Wisconsin 53715
}

\begin{abstract}
We report serial measurements of bone mineral content (BMC), bone width (BW, a measure of appositional bone growth), and the ratio of $\mathrm{BMC}$ : $\mathrm{BW}$ by photon absorptiometry of the left radius through the first 10 wk of life in 38 very low birth weight premature infants (birth weight $<1300 \mathrm{~g}$, gestational age $<32$ wk). Fifteen of 38 infants developed bronchopulmonary dysplasia (BPD) and as a group they could not be distinguished from the 23 infants without BPD, despite the high association between BPD and metabolic bone disease. As BPD occurred in the smaller patients, the BPD group had a significantly lower mean birth weight and mean gestational age as compared to controls $(950 \pm 125$ g versus $1119 \pm 149$, and $28.0 \pm$ 0.8 versus $29.0 \pm 1.3$ wk). For both control and BPD groups, BMCs did not differ and remained relatively unchanged throughout the first 10 wk of life, lagging significantly behind the intrauterine rate as defined by measuring BMC in 175 infants of varying gestational ages during the first few days of life. BW also did not differ during this period between groups. BW did increase significantly in both groups (from $3.2 \pm 0.3$ to $3.9 \pm 0.4 \mathrm{~mm}$ in the controls and from 3.0 \pm 0.3 to $3.8 \pm 0.4 \mathrm{~mm}$ in the BPD group), but remained significantly delayed compared to the intrauterine rate. In both groups, BMC remained relatively constant despite increasing $\mathrm{BW}$ and thus $\mathrm{BMC} / \mathrm{BW}$ decreased during the first $10 \mathrm{wk}$ of life (from 11.5 \pm 1.3 to $10.2 \pm 1.9$ in the controls and from $11.0 \pm 1.3$ to $8.6 \pm 2.2$ in the BPD group). Thus in very low birth weight infants, with and without $B P D$, we have clearly documented a decrease in BMC compared to the intrauterine values. This occurs despite appositional and overall skeletal growth, indicating a disorder of formation and/or remodeling of growing cortical bone. (Pediatr Res 20: 925-928, 1986)
\end{abstract}

\section{Abbreviations}

BMC, bone mineral content

BW, bone width

BPD, bronchopulmonary dysplasia

VLBW, very low birth weight

In a previous publication we demonstrated that photon absorptiometry of the radius can be used with high accuracy, precision, and reproducibility to determine BMC and BW in vivo in fullterm and preterm newborn infants (1). It was found that $\mathrm{BMC}$ has a high correlation with gestational age, birth weight,

Received February 24, 1986; accepted May 12, 1986

Reprints: Frank R. Greer, M.D., Wisconsin Perinatal Center, 202 South Park Street, Madison, WI 53715.

Supported by a grant from Ross Laboratories, Columbus, $\mathrm{OH}$.

${ }^{1}$ Presented at the American Society for Bone and Mineral Research, June 15$18,1985$. and BW at birth. Because of the direct relationship between BMC and $\mathrm{BW}$ we speculated that the ratio of $\mathrm{BMC}$ to $\mathrm{BW}$ would be useful in identifying disorders of bone mineral metabolism in low birth weight infants (1).

In the present study, we report serial measurements of BMC and $\mathrm{BW}$ through the first $10 \mathrm{wk}$ of life in 38 VLBW premature infants. We hypothesized that during this period of active growth in weight and length, BW (a measure of bone diameter and hence of appositional bone growth in infancy and childhood) would increase secondary to increased matrix formation (2); however, we predicted BMC would decrease or remain unchanged due to insufficient mineral intake compared to that necessary to achieve the intrauterine rate of bone mineralization (1). Following entry into the study, 15 of 38 infants developed BPD and we hypothesized that as a group they could be distinguished from the 23 infants without BPD because of the high association between BPD and metabolic bone disease (3). We anticipated that the ratio of $\mathrm{BMC}$ to $\mathrm{BW}$ would be lower in the BPD group compared to controls.

\section{MATERIALS AND METHODS}

Population. Thirty-eight VLBW infants (birth weight $<1300$ $\mathrm{g}$, gestational age $<32 \mathrm{wk}$ ) were recruited for this study during the 1st wk of life, after obtaining parental informed consent. Thirty-five infants were white and three infants were black. All infants were appropriate for gestational age. Gestational age was determined from the history of the last menstrual period and corroborated by the Ballard examination for those infants greater than $27 \mathrm{wk}$ gestational age (4). For those infants less than or equal to $27 \mathrm{wk}$ gestation, fetal ultrasound measurements were used as the second corroborator of gestational age, when available from the department of obstetrics. If there was more than a 2 wk discrepancy between the two determinations of gestational age, the infant was excluded from the study. All infants were admitted to the neonatal intensive care unit at Madison General Hospital and all were free from major congenital malformations.

Of these 38 infants, 15 were diagnosed subsequently as having BPD. All infants with BPD had the initial diagnosis of the respiratory distress syndrome, required supplemental oxygen for a minimum of 30 days, and had a chest $x$-ray diagnosis of BPD (hyperexpansion, interstitial densities, focal emphysema) (5). For purposes of comparison, the remaining 23 infants were designated as controls.

Photon absorptiometry. BMC and bone width were measured by a photon absorptiometric system (Lunar Radiation Inc., Madison, WI) in which a collimated $2 \mathrm{~mm}$ diameter photon beam from a low activity [ $\left.{ }^{125} \mathrm{I}\right]$ "spent source" $(20-50 \mathrm{mCi})$ was passed beneath the one-third distal radius (shaft) of the left forearm. The system has been previously described in detail (1). Measurements of BMC and bone width were made within the 1 st wk of life and subsequently at biweekly intervals. Accuracy, precision, and reproducibility of this system used by us in newborn infants have been published (1). Immediate reproducibility 
(without repositioning the arm) for four to six scans performed for each determination of $\mathrm{BMC}$ and $\mathrm{BW}$ is good with a mean coefficient of variation of $3.9 \%$ for BMC and $3.6 \%$ for BW (1). The "repositioning error," determined by repeating measurements of BMC and BW after repositioning the arm in 74 infants is relatively small. The mean percent difference between readings for BMC is $5.5 \pm 4.9(\mathrm{SD})$ and for BW $5.1 \pm 3.5$.

Statistical analysis. Data analysis was by Student's $t$ test. Because of the possibility of spurious "significant" findings from multiple statistical analyses, analysis of variance with repeated measures was performed for the longitudinal data to confirm all significant differences. Standard linear regression was also used where appropriate.

Miscellaneous. Weight and intakes of formula or human milk were recorded daily as part of routine hospital care. Length was measured biweekly on a single infant measuring board from Jim's Instruments Manufacturing, Inc., Iowa City, IA.

"Intrauterine" values for $B M C$ and $B W$. The rates of intrauterine bone mineralization and growth in bone width were determined by measuring BMC and BW in 175 Caucasian appropriate for gestational age infants in the first 3 days of life. Infants ranged from 22-42 wk gestation. Results on 114 infants have been previously reported (1). Of the 61 additional infants reported here, 40 infants were premature ( $<37$ wk gestational age).

\section{RESULTS}

The results for $\mathrm{BMC}, \mathrm{BW}$, and $\mathrm{BMC}: \mathrm{BW}$ with $\mathrm{SDs}$ in 175 infants of varying gestational ages during the first three days of life are shown in Table 1. Data from Table 1 were used to construct graphs of intrauterine $\mathrm{BMC}, \mathrm{BW}$, and $\mathrm{BMC} / \mathrm{BW}$ versus postconceptional age used in subsequent figures (1-3).

Table 2 contains the clinical data on 38 patients followed longitudinally in this study. As BPD occurred in the smaller patients, the infants in the BPD group had a significantly lower mean birth weight and mean gestational age as compared to controls. In Table 2, it is also apparent that infants with BPD had longer periods of assisted ventilation, supplemental oxygen therapy, and hospitalization. In addition, 11 of 15 infants with BPD were on chronic furosemide therapy $(1 \mathrm{mg} / \mathrm{kg}$ day parenterally, $2 \mathrm{mg} / \mathrm{kg} /$ day orally). The mean duration of furosemide

Table 1. Results of radial $B M C, B W$, and $B M C: B W$ in 175 appropriate for gestational age infants from 22 to $42 \mathrm{wk}$ gestation

\begin{tabular}{crcccccc}
\hline $\begin{array}{c}\text { Gestational } \\
\text { age (wk) }\end{array}$ & $n$ & $\begin{array}{c}\text { BMC } \\
(\mathrm{mg} / \mathrm{cm})\end{array}$ & \multicolumn{1}{c}{ SD } & $\begin{array}{c}\text { BW } \\
(\mathrm{mm})\end{array}$ & SD & BMC/BW & SD \\
\hline $22-23$ & 3 & 17.6 & 3.1 & 2.7 & 0.3 & 6.65 & 0.68 \\
$24-25$ & 4 & 27.2 & 6.6 & 2.8 & 0.4 & 9.71 & 1.58 \\
$26-27$ & 8 & 31.8 & 7.4 & 3.1 & 0.3 & 10.38 & 1.85 \\
$28-29$ & 21 & 37.2 & 6.3 & 3.3 & 0.4 & 11.19 & 1.58 \\
$30-31$ & 22 & 41.3 & 6.3 & 3.4 & 0.3 & 12.01 & 1.50 \\
$32-33$ & 17 & 47.7 & 9.1 & 3.7 & 0.5 & 12.83 & 1.54 \\
$34-35$ & 13 & 55.2 & 11.0 & 4.0 & 0.5 & 13.74 & 1.61 \\
$36-37$ & 19 & 72.6 & 14.1 & 4.5 & 0.5 & 16.03 & 2.13 \\
$38-39$ & 31 & 91.0 & 17.1 & 5.0 & 0.5 & 17.97 & 2.36 \\
$40-41$ & 32 & 93.2 & 18.2 & 5.2 & 0.8 & 17.91 & 2.07 \\
42 & 5 & 105.9 & 24.4 & 5.5 & 1.0 & 19.16 & 1.41 \\
\hline
\end{tabular}

therapy was $109 \pm 56$ days, eight of 11 infants remaining on furosemide for the duration of the study. Nutritionally, all infants received total parenteral nutrition initially and nine infants in each group received $90 \%$ or more of their oral calories as human milk. The standard formula utilized was Similac, $20 \mathrm{cal} \mathrm{oz}$. Ten infants in each group received oral calcium and phosphate supplements at some time during the course of the study. Decision for supplementation was at the discretion of the attending physician, the most common reason for supplementation being the low $\mathrm{Ca} / \mathrm{P}$ intakes in those infants fed human milk. By $\mathrm{Ca} / \mathrm{P}$ supplements is meant a high $\mathrm{Ca} / \mathrm{P}$ containing formula (Similac Special Care, Ross Laboratories, Columbus, $\mathrm{OH}$ ) or direct supplements of $\mathrm{Ca}$ (calcium gluconate) and $\mathrm{P}$ (potassium phosphate) added to the feedings, increasing the elemental $\mathrm{Ca}$ intake to 150 $\mathrm{mg} / \mathrm{kg} /$ day and the elemental $\mathrm{P}$ intake to $100 \mathrm{mg} / \mathrm{kg} /$ day. Dietary intake data for $\mathrm{Ca}, \mathrm{P}$, and vitamin $\mathrm{D}$ are given in Table 3 . Only at 38-39 wk did the infants with BPD achieve a significantly higher intake of $\mathrm{Ca}, \mathrm{P}$, and vitamin $\mathrm{D}$ compared to controls. In general intakes of $\mathrm{Ca}$ and $\mathrm{P}$ were less than the intrauterine accretion rates. Only the BPD infants achieved an intake of $\mathrm{Ca}$ comparable to the intrauterine $\mathrm{Ca}$ accretion rate of $150 \mathrm{mg} / \mathrm{kg} /$ day by 38-39 wk gestational age (6-8). Presumably the $\mathrm{Ca}$ retention rate in these infants was still less than $150 \mathrm{mg} / \mathrm{kg} /$ day.

Data from the measurements made by photon absorptiometry are depicted in Figues 1 through 3 . In Figure 1, BMC $(\mathrm{mg} / \mathrm{cm})$ versus weeks postconception is shown for control and BPD groups. Also shown is the intrauterine curve for bone mineralization, drawn from the data in Table 1. Although the BMC for the 23 controls was higher than the 15 infants with BPD throughout the study, at no time did this difference reach statistical significance. However, by $32 \mathrm{wk}$, both groups were significantly below the intrauterine curve for $\mathrm{BMC}(p<0.01)$, and remained so throughout the study. For both control and BPD groups BMC remained relatively unchanged throughout the first $10 \mathrm{wk}$ of life. Thus BMC did not correlate with postconceptional age in these groups unlike the infants utilized for the intrauterine values (Table 1) where there was a very high correlation between BMC and postconceptional age $(r=0.92)$. We also found no correlation in either BPD or control groups between $\mathrm{BMC}$ and $\mathrm{Ca} / \mathrm{P}$ intakes. There was also no difference in BMC between infants fed formula and human milk.

Figure 2 gives the data for bone width $(\mathrm{mm})$ a measure of appositional bone growth. Throughout the study there was no difference in BW between BPD and control groups and both lagged significantly behind the intrauterine curve for BW (also shown in Fig. 2) by $34 \mathrm{wk}(p<0.01)$. However, unlike BMC, BW in both groups significantly increased between $30-31$ and 38-39 wk $(p<0.001)$ and was significantly correlated with postconceptional age $(r=0.82 p<0.001)$ as in the infants utilized for the intrauterine values (Table 1). Also, total body length increased significantly $(p<0.001)$ in the control $(37.3 \pm$ 1.9 to $44.9 \pm 2.2 \mathrm{~cm})$ and BPD $(36.0 \pm 2.6$ to $43.8 \pm 1.8 \mathrm{~cm})$ groups reflecting overall skeletal growth

Figure 3 shows the ratio of BMC to BW during the study period. In the intrauterine data (from Table 1), BMC/BW linearly increases with gestational age $(r=0.97)$. In both the control and BPD groups, however, BMC remains relatively constant despite increasing $\mathrm{BW}$. Thus $\mathrm{BMC} / \mathrm{BW}$ ratio does not increase but decreases in both groups with increasing age, although the decrease is not statistically significant.

Table 2. Patient clinical data $( \pm S D)$

\begin{tabular}{lcccccccc}
\hline & & \multicolumn{3}{c}{$\begin{array}{c}\text { Respiratory } \\
\text { distress } \\
\text { syndrome } \\
\text { (yes) }\end{array}$} & $\begin{array}{c}\text { Assisted } \\
\text { ventilation } \\
\text { (days) }\end{array}$ & $\begin{array}{c}\text { Supplemental } \\
\mathrm{O}_{2} \text { (days) }\end{array}$ & $\begin{array}{c}\text { Hospital } \\
\text { stay (days) }\end{array}$ & $\begin{array}{c}\text { Furosemide } \\
\text { RX (yes) }\end{array}$ \\
\hline Control & 23 & $1119 \pm 149$ & $29.0 \pm 1.3$ & 14 & $5.05 \pm 5.5$ & $10.5 \pm 15.4$ & $62.5 \pm 14.3$ & 0 \\
BPD & 15 & $950 \pm 125^{*}$ & $28.0 \pm 0.8^{*}$ & 15 & $27.5 \pm 21$ & $101.5 \pm 91$ & $90.4 \pm 16.6$ & 11 \\
\hline
\end{tabular}

$* p<0.01$ compared to control. 
Table 3. Patient intake data $( \pm S D)$ for weeks postconception

\begin{tabular}{|c|c|c|c|c|c|}
\hline & $30-31$ & $32-33$ & $34-35$ & $36-37$ & $38-39$ \\
\hline \multicolumn{6}{|c|}{$\mathrm{Ca} \mathrm{mg} / \mathrm{kg} /$ day } \\
\hline Control & $\begin{array}{c}56 \pm 33 \\
(17)^{*}\end{array}$ & $\begin{array}{c}104 \pm 47 \\
(23)\end{array}$ & $\begin{array}{c}114 \pm 50 \\
(23)\end{array}$ & $\begin{array}{c}111 \pm 46 \\
(21)\end{array}$ & $\begin{array}{c}88 \pm 39 \\
(13)\end{array}$ \\
\hline BPD & $\begin{array}{c}51 \pm 29 \\
(15)\end{array}$ & $\begin{array}{c}89 \pm 47 \\
(15)\end{array}$ & $\begin{array}{c}124 \pm 70 \\
(15)\end{array}$ & $\begin{array}{c}134 \pm 57 \\
(15)\end{array}$ & $\begin{array}{c}155 \pm 55 \dagger \\
\text { (12) }\end{array}$ \\
\hline \multicolumn{6}{|c|}{$\mathrm{PO}_{4} \mathrm{mg} / \mathrm{kg} /$ day } \\
\hline Control & $\begin{array}{c}49 \pm 15 \\
(17)\end{array}$ & $\begin{array}{c}61 \pm 23 \\
(23)\end{array}$ & $\begin{array}{c}67 \pm 25 \\
(23)\end{array}$ & $\begin{array}{c}65 \pm 26 \\
(21)\end{array}$ & $\begin{array}{c}53 \pm 27 \\
(13)\end{array}$ \\
\hline BPD & $\begin{array}{c}51 \pm 29 \\
(15)\end{array}$ & $\begin{array}{c}89 \pm 47 \\
(15)\end{array}$ & $\begin{array}{c}124 \pm 70 \\
(15)\end{array}$ & $\begin{array}{c}134 \pm 57 \\
(15)\end{array}$ & $\begin{array}{c}155 \pm 55 \ddagger \\
(12)\end{array}$ \\
\hline \multicolumn{6}{|c|}{ VIT D IU/day } \\
\hline Control & $\begin{array}{c}137 \pm 132 \\
(17)\end{array}$ & $\begin{array}{c}336 \pm 133 \\
(23)\end{array}$ & $\begin{array}{c}443 \pm 123 \\
(23)\end{array}$ & $\begin{array}{c}440 \pm 105 \\
(21)\end{array}$ & $\begin{array}{c}394 \pm 82 \\
(13)\end{array}$ \\
\hline BPD & $\begin{array}{c}93 \pm 84 \\
(15)\end{array}$ & $\begin{array}{c}240 \pm 167 \\
\text { (15) }\end{array}$ & $\begin{array}{c}379 \pm 144 \\
(15)\end{array}$ & $\begin{array}{c}410 \pm 159 \\
(15)\end{array}$ & $\begin{array}{c}490 \pm 139 \S \\
(12)\end{array}$ \\
\hline
\end{tabular}

\section{* Subjects.}

$\dagger p<0.01$ compared to control.

$\ddagger p<0.02$ compared to control.

$\S p<0.05$ compared to control.

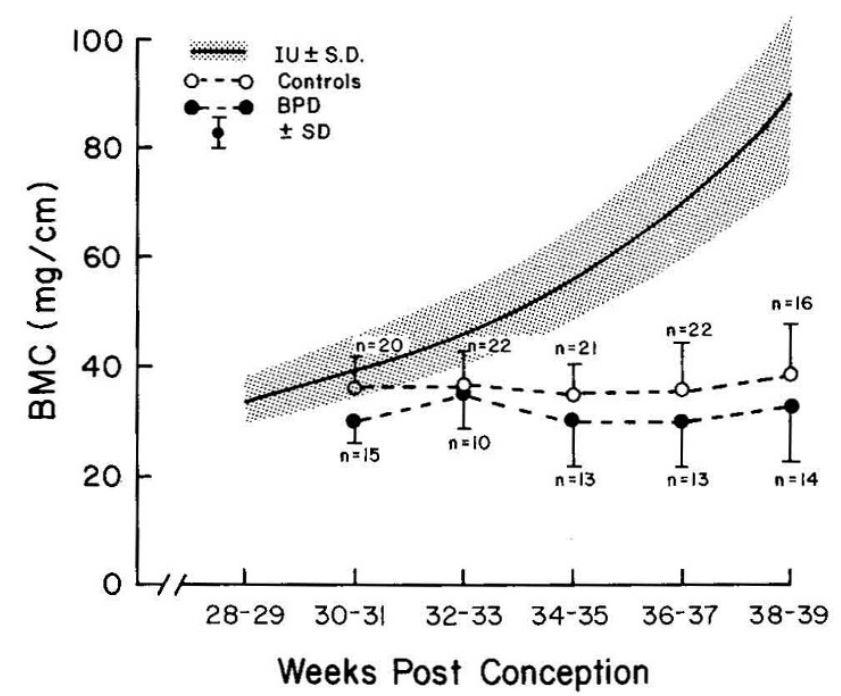

Fig. 1. Bone mineral content $(\mathrm{mg} / \mathrm{cm})$ as measured by photon absorptiometry versus weeks postconceptional age in growing VLBW premature infants with (BPD) and without (controls) bronchopulmonary dysplasia. The unbroken, shaded line represents the intrauterine change in bone mineral content $\pm 1 \mathrm{SD}$ (see text).

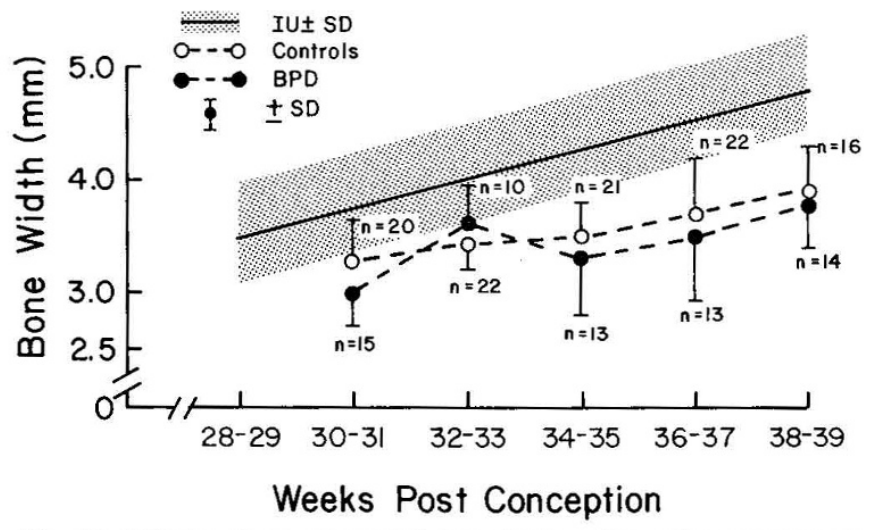

Fig. 2. BW $(\mathrm{mm})$ as measured by photon absorptiometry versus weeks postconceptional age in growing VLBW premature infants with (BPD) and without (controls) bronchopulmonary dysplasia. The unbroken, shaded line represents the intrauterine change in bone width \pm 1 $\mathrm{SD}$ (see text).

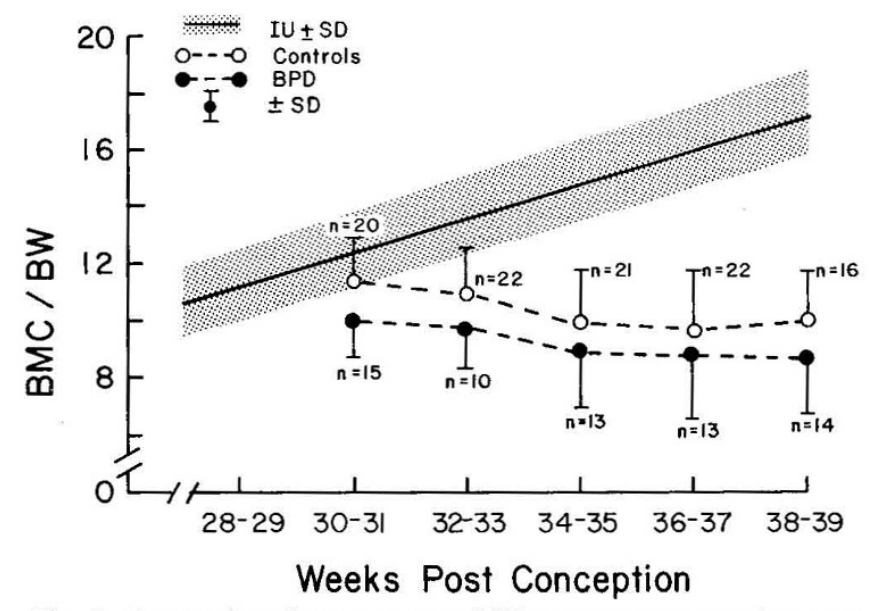

Fig. 3. Bone mineral content over BW versus postconceptional age, calculated from values used in Figures 1 and 2, for BPD and control infants. The unbroken, shaded line represents the intrauterine change in $\mathrm{BMC} / \mathrm{BW}$ ratio $\pm 1 \mathrm{SD}$ (see text).

\section{DISCUSSION}

These data clearly demonstrate a low bone mineral content despite appositional growth of cortical bone (as measured by radial bone width) in VLBW infants compared to the intrauterine values for BMC during the first $10 \mathrm{wk}$ of life (Fig. 1). Although appositional bone growth occurred, it was still considerably less than the intrauterine rate (Fig. 2). Overall skeletal growth is documented by increases in length during the study period. The fact that BMC and appositional bone growth (BW) is decreased in these infants during a time when skeletal growth is occurring, suggests a disorder of formation and/or remodeling of cortical bone. This is supported by many reports of diffusely demineralized bones in routine $x$-rays of some growing premature infants with metabolic bone disease $(9-12)$. This disorder may be secondary to a defect in the overall mineralization process of cortical bone or perhaps due to extensive cortical thinning and remodeling of normally mineralized bone, or a combination thereof.

One previous group has reported delay in BMC in growing premature infants using photon absorptiometry $(13,14)$. In the first of their reports only three infants less than $32 \mathrm{wk}$ gestation were studied and no measurements of bone width were made. Overall skeletal growth was not reported. In six infants, 31-32 
wk gestation, no increase in $\mathrm{BMC}$ was noted from birth to 10 wk. In the second of these reports which included infants from the first, an increase in BMC in infants 28-32 wk gestation on both a standard and experimental formula (high $\mathrm{Ca}$, high $\mathrm{P}$ ) was reported during the first $10 \mathrm{wk}$ of life (14). No measurements of BW were made. It is hard to reconcile our own data with these somewhat conflicting reports, but it is apparent that our population was smaller and of a lower mean gestational age.

In this study, intakes of $\mathrm{Ca}$ and $\mathrm{P}$ were generally less than those necessary to support the intrauterine rate of bone mineralization (6-8). The insufficient intakes of $\mathrm{Ca}$ and $\mathrm{P}$ would explain the lack of correlation between BMC and $\mathrm{Ca}$ and $\mathrm{P}$ intakes and would also explain the lack of catch up bone mineralization in either group (Fig. 1). We could not rule out that catch-up bone mineralization might have occurred with higher $\mathrm{Ca} / \mathrm{P}$ intakes as has been reported in other studies $(14,15)$.

It is possible that the low bone mineral content is in part due to a vitamin $\mathrm{D}$ deficiency rather than solely an inadequate intake of $\mathrm{Ca}$ and $\mathrm{P}$. We did not measure serum vitamin $\mathrm{D}$ levels in these infants, although others have reported serum levels of 1,25 $(\mathrm{OH})_{2}$ vitamin D (the most active metabolite of vitamin D) to be high in premature infants on similar intakes of vitamin D (16). All infants in this study received the recommended vitamin $\mathrm{D}$ intake for premature infants of $400 \mathrm{IU} /$ day once full oral feeds were achieved and this was continued throughout the study (17, 18).

We were surprised that bone mineral content was delayed to an equal degree in both control and BPD groups. This is despite available evidence which suggests that VLBW infants with BPD are at risk for metabolic bone disease (2). Such infants generally have a more complicated hospital course, require chronic fluid restriction (further restricting $\mathrm{Ca}$ and $\mathrm{P}$ intakes), and receive regular furosemide therapy as part of their treatment. Our infants with BPD were "sicker" than the control infants as judged by duration of assisted ventilation, hospitalization, and supplemental oxygen therapy. Eleven of 15 infants with BPD were also on chronic furosemide therapy, which is known to increase urinary calcium losses in premature infants $(19,20)$. Our data would suggest factors other than the presence or absence of BPD are responsible for the low bone mineral content in very premature infants. Extreme prematurity and inadequate intakes of $\mathrm{Ca}$ and $\mathrm{P}$ in these infants with or without BPD seem to be very important. Although the BMC was generally less in BPD than controls, the difference was not significant. Our two groups were not controlled for birth weight and gestational age which would probably account for much of this observed difference in BMC as our infants with BPD were of significantly smaller birth weight and gestational age (Table 1). As documented previously, BMC correlates with birth weight and gestational age (1).

Other investigators have reported bone hypomineralization in growing premature infants by photon absorptiometry as well as by other less sensitive techniques. However, in this study we have clearly documented a decrease in BMC despite appositional and overall skeletal growth, indicating a disorder of formation and/ or remodeling of growing cortical bone. The fact that this occurred to an equal degree in growing VLBW premature infants with and without bronchopulmonary dysplasia was unexpected.

\section{REFERENCES}

1. Greer FR, Lane J, Weiner S, Mazess RB 1983 An accurate and reproducible absorptiometric technique for determining bone mineral content in newborn infants. Pediatr Res 17:259-262

2. Garn SM 1970 The Earlier Gain and the Later Loss of Cortical Bone. Charles C Thomas, Springfield, IL, pp 14-16

3. Greer FR, Tsang RC 1986 Calcium and vitamin D metabolism in the term and low birth weight infants. Review of recent investigations. Perinatol Neonatol 9:14-21

4. Ballard JL, Kazmaier NK, Driver M 1979 A simplified score for assessment of fetal maturation of newly born infants. J Pediatr 95:769-774

5. Northway WH, Rosan RC, Porter DG 1967 Pulmonary disease following respirator therapy of hyaline membrane disease: bronchopulmonary dysplasia. N Engl J Med 276:357-368

6. Ziegler EE, O'Donnell AM, Nelson SE, Fomon SJ 1976 Body composition of the reference fetus. Growth 40:329-341

7. Forbes GB 1976 Calcium accumulation by the human fetus. Pediatrics 57:976977

8. Shaw JCL 1973 Parenteral nutrition in the management of sick low birth weight infants. Pediatr Clin North Am 20:333-358

9. Koo WW, Gupta JM, Nayanar VV, Wilkinson M, Posen S 1982 Skeletal changes in preterm infants. Arch Dis Child 57:447-452

10. Hillman LS, Hoff N, Salmons S, Martin L, McAlister W, Haddad J 1985 Mineral homeostasis in very premature infants: serial evaluation of serum 25-hydroxyvitamin D, serum minerals and bone mineralization. J Pediatr 106:970-980

11. Hillman LS, Salmons SJ, Slatopolsky E, McAlister WH 1985 Serial serum 25hydroxyvitamin $\mathrm{D}$ and mineral homeostasis in very premature infants fed preterm human milk. J Pediatr Gastroenterol Nutr 4:762-770

12. Laing IA, Glass EJ, Hendry GMA, Westwood A, Elton RA, Lang M, Hume R 1985 Rickets of prematurity: calcium and phosphorus supplementation. J Pediatr 106:265-268

13. Minton SD, Steichen JJ, Tsang RC 1979 Bone mineral content in term and preterm appropriate for gestational age infants. J Pediatr 95:1037-1042

14. Steichen JJ, Gratton TL, Tsang RC 1980 Osteopenia of prematurity: the cause and possible treatment. J Pediatr 96:528-534

15. Greer FR, Steichen JJ, Tsang RC 1982 Effects of increased calcium, phosphorus, and vitamin $D$ intake on bone mineralization in very low birth weight infants fed formulas with Polycose and medium-chain tri-glycerides. J Pediatr 100:951-955

16. Markestad T, Aksnes L, Finne PH, Aarskog D 1984 Plasma concentrations of vitamin D metabolites in premature infants. Pediatr Res 18:269-272

17. American Academy of Pediatrics, Committee on Nutrition 1977 Nutritional needs of low birth weight infants. Pediatrics 60:519-530

18. Greer FR, Tsang RC 1985 Calcium, phosphorus, magnesium, and vitamin D requirements for the preterm infant. In: Tsang RC (ed) Vitamin and Mineral Requirements in Preterm Infants. Marcel Dekker, New York, pp 118-136

19. Hufnagle KG, Shadid NK, Penn D, Cacciarelli A, Williams P 1982 Renal calcifications: a complication of long-term furosemide therapy in preterm infants. Pediatrics 70:360-363

20. Glasier CM, Stoddard RA, Ackerman NB, McCardy FA, Null DM, deLemos RA 1983 Nephrolithiasis in infants: association with chronic furosemide therapy. Am J Radiol 140:107-108 